\title{
Motorcycle On-Road Driving Parameters Influencing Fuel Consumption and Emissions on Congested Signalized Urban Corridor
}

\author{
Atthapol Seedam, ${ }^{1}$ Thaned Satiennam, ${ }^{1}$ Thana Radpukdee, ${ }^{1}$ Wichuda Satiennam, ${ }^{1}$ \\ and Vatanavongs Ratanavaraha ${ }^{2}$ \\ ${ }^{1}$ Faculty of Engineering, Khon Kaen University, Khon Kaen 40002, Thailand \\ ${ }^{2}$ School of Transportation Engineering, Suranaree University of Technology, Nakhon Ratchasima 30000, Thailand
}

Correspondence should be addressed to Thaned Satiennam; sthaned@kku.ac.th

Received 21 January 2017; Accepted 12 March 2017; Published 9 May 2017

Academic Editor: Jose E. Naranjo

Copyright (C) 2017 Atthapol Seedam et al. This is an open access article distributed under the Creative Commons Attribution License, which permits unrestricted use, distribution, and reproduction in any medium, provided the original work is properly cited.

\begin{abstract}
This study aims to find the on-road driving parameters influencing fuel consumption and emissions of motorcycle driving on a congested signalized urban corridor. A motorcycle onboard measurement system was developed to measure instantaneously and continuously record on-road driving data, including speed-time profile, emissions, and fuel consumption, by the second. The test motorcycles were driven by 30 sample motorcyclists on a signalized urban corridor in Khon Kaen City, Thailand, to collect their on-road driving behavior during the morning peak period. Cluster analysis was applied to analyze collected driving data and to categorize the drivers by level of fuel consumption and on-road driver behavior. The on-road driving parameter influencing fuel consumption and emissions was then determined. Results revealed that proportion of idle time significantly influenced fuel consumption and emissions of motorcycle driving on a congested signalized urban corridor, though aggressive driving behavior, hard acceleration and deceleration, did not have the same kind of influence.
\end{abstract}

\section{Introduction}

The number of motorcycles in many motorcycle-dominated countries presently has increased rapidly. The motorcycles have the largest share, accounting for more than $90 \%$ of the road transport fleet in Hanoi, Vietnam [1]. The number of registered motorcycles increased to 20 million vehicles, representing $56 \%$ of all vehicles in Thailand [2]. This high demand has increased fuel consumption and is a direct cause of a large amount of air pollution emissions. The Asian Development Bank, ADB [3], reported that the MC fleet emitted about $54 \%$ of $\mathrm{CO}$ and hydrocarbon (HC) pollution at roadside in Hanoi. Wang et al. [4] estimated that motorcycles emitted approximately $45.0 \%$ of the Volatile Organic Compounds (VOC) and approximately $36.3 \%$ of the Particulate Matter (PM) of the total emissions from vehicles in Shanghai, China. In India, Sahu et al. [5] estimated that motorcycles emitted approximately $37 \%$ of the total emissions from carbon monoxide (CO) in on-road transport. Fukuda et al. [6] found that, compared with passenger cars, motorcycles consumed fuel and emitted approximately $30 \%$ and $27 \%$ of carbon dioxide $\left(\mathrm{CO}_{2}\right)$, respectively, in Khon Kaen City, Thailand. Thus, fuel consumption and emissions from motorcycles in developing cities are problems that need immediate action.

World Conference on Transport Research Society [7] proposed the CUTE matrix, introducing three strategies, including AVOID, SHIFT, and IMPROVE, to reduce fuel consumption and emissions from the transport sector. The researchers in motorcycle-dominated countries have proposed measures according to this matrix, including AVOID (e.g., on-road ecodriving behavior), SHIFT (e.g., shift to public transport) [8], and IMPROVE (e.g., improving motorcycle conformance to the EURO3 standard (Oanh et al., 2012), as well as changing motorcycles to electric motorcycles [9]). On-road ecodriving behavior has been reported to reduce fuel consumption and 
emissions from many previous researches [10-12]. The smooth driving behavior, such as smooth acceleration and deceleration, results in lower fuel consumption and emissions compared with aggressive driving behavior, such as hard acceleration and braking. Many investigations have reported that maintaining an on-road ecodriving behavior can reduce fuel consumption by $5-30 \%$ [11-13].

However, results of current review and assessment on numerous previous studies revealed that there was some doubt over effectiveness of ecodriving behavior in such congested urban circumstances [14]. Nevertheless, there is also a lack of studies on on-road driving behavior, influencing fuel consumption and emissions, of two-wheel vehicles, especially on congested urban intersections where motorcycle generally penetrate into the stop line by overtaking a queue of other larger vehicles under congestion. They make a stop at signalized intersections to wait for green lights less than other larger vehicles. The objective of this research is therefore to explore the on-road driving parameters influencing fuel consumption and emissions of motorcycle driving on a congested and dense signalized urban road. In this paper, the next section describes the research methodology. Section 3 presents the results and discussion. Section 4 presents the conclusions and recommendations.

\section{Research Methodology}

2.1. Onboard Measurement System Development. This study further developed the onboard measurement system previously developed from previous studies $[15,16]$ to instantaneously measure and continuously measure speed-time profile, fuel consumption, and exhaust emissions of motorcycle driving on the road. A fuel injection sensor was installed at the fuel injection point in order to measure time injection. This data would be further applied to calculate the fuel consumption of the motorcycle [17-19]. A mobile exhaust gas analyzer was installed on the rear side of the motorcycle to measure the amount of $\mathrm{CO}$ and $\mathrm{CO}_{2}$ emissions. The suction tube of the equipment can be connected to the motorcycle's exhaust pipe. Accordingly, the suction tube sucks the exhaust gas into the equipment to analyze the amount of emissions. The analyzed data is then displayed on the equipment monitor and recorded in the memory storage per second.

Consequently, the developed onboard measurement system consists of several units, including the data logger for processing and recording the collected data, rear wheel speed sensor for measuring speed, fuel injection sensor for calculating fuel consumption, and an exhaust gas analyzer for measuring the amount of exhaust emissions.

The installing positions of onboard system units are displayed in Figure 1. The test motorcycle was driven on a specific route to measure and record speed-time profile as well as exhaust emissions in order to test the accuracy of the developed motorcycle onboard measurement system. All test results implied that the developed onboard measurement system could accurately measure and record the on-road driving data of the motorcycle.
2.2. Collection of On-Road Driving Data. This study selected Khon Kaen City as a study area since this city represents the characteristics of developing Asian developing cities, that is, highly congested traffic conditions, especially during peak hours, and a large number of motorcycles, approximately $50 \%$ of mode share [20]. Khon Kaen province is located in the Northeast of Thailand and Khon Kaen City covers an area of $228 \mathrm{~km}^{2}$. Recently, the city's population was estimated at 250,000. The study road was a section of Sri Chan Rd., the main road passing through the CBD of Khon Kaen City as displayed in Figure 2. The selected study section was a section of $3.6 \mathrm{~km}$ length located with 8 closing signalized intersections as displayed in Figure 3. It encounters serious traffic congestion with E-F level of service during morning and evening peak periods [20].

The selected motorcycle size was a 4 -stroke $108 \mathrm{~cm}^{3}$ motorcycle which is a small-sized motorcycle commonly used in Thailand. The onboard measurement system was installed on the selected motorcycles to measure on-road driving patterns and exhaust emissions. The 30 sample drivers were selected to ride on this corridor during the morning peak hours of between 7:00 a.m. to 9:00 a.m. to collect onroad driving data for a total of 112 hours. All driving tests started with a full fuel in the tank. The study chose to collect data during the peak morning period as the most critical congestion period occurs during this time of the day. Thus, each driver would randomly encounter different in-traffic conditions and daytime signal timing.

2.3. Category Analysis of Driving Data. Cluster analysis was applied to uncover driving parameters influencing fuel consumption and emissions. The collected data sets of 30 drivers were categorized by level of fuel consumption and driving behavior. The study categorized the drivers by fuel consumption to determine which driving parameter is influencing fuel consumption and emissions. The study also categorized the drivers by driving behavior to explore whether the ecodriving behavior of motorcyclists on congested and dense signalized urban road would influence fuel consumption and emissions. The aggressive drivers were recognized with acceleration and deceleration higher than nonaggressive drivers.

\section{Results and Discussion}

3.1. Results of On-Road Driving Data Collection. The onroad driving data from 29 drivers (except driver number 27) was able to be completely collected. In total, 112 hours of driving data were collected. The parameters of driving behavior, determined according to many previous studies $[16,21-24]$, as well as fuel consumption and emissions from each driver/motorcycle were calculated. Driving behavior parameters included average running speed (excluding idling period) $(\mathrm{km} / \mathrm{h})$, average acceleration or a rate of change of speed above $0.27\left(\mathrm{~m} / \mathrm{s}^{2}\right)$, average deceleration or rate of change of speed below $-0.27\left(\mathrm{~m} / \mathrm{s}^{2}\right)$, time spent at idle or portion of time at zero speed (\%), time spent accelerating or portion of time accelerating for $\geq 0.27 \mathrm{~m} / \mathrm{s}^{2}(\%)$, time spent decelerating or portion of time decelerating for $\leq-0.27 \mathrm{~m} / \mathrm{s}^{2}$ 


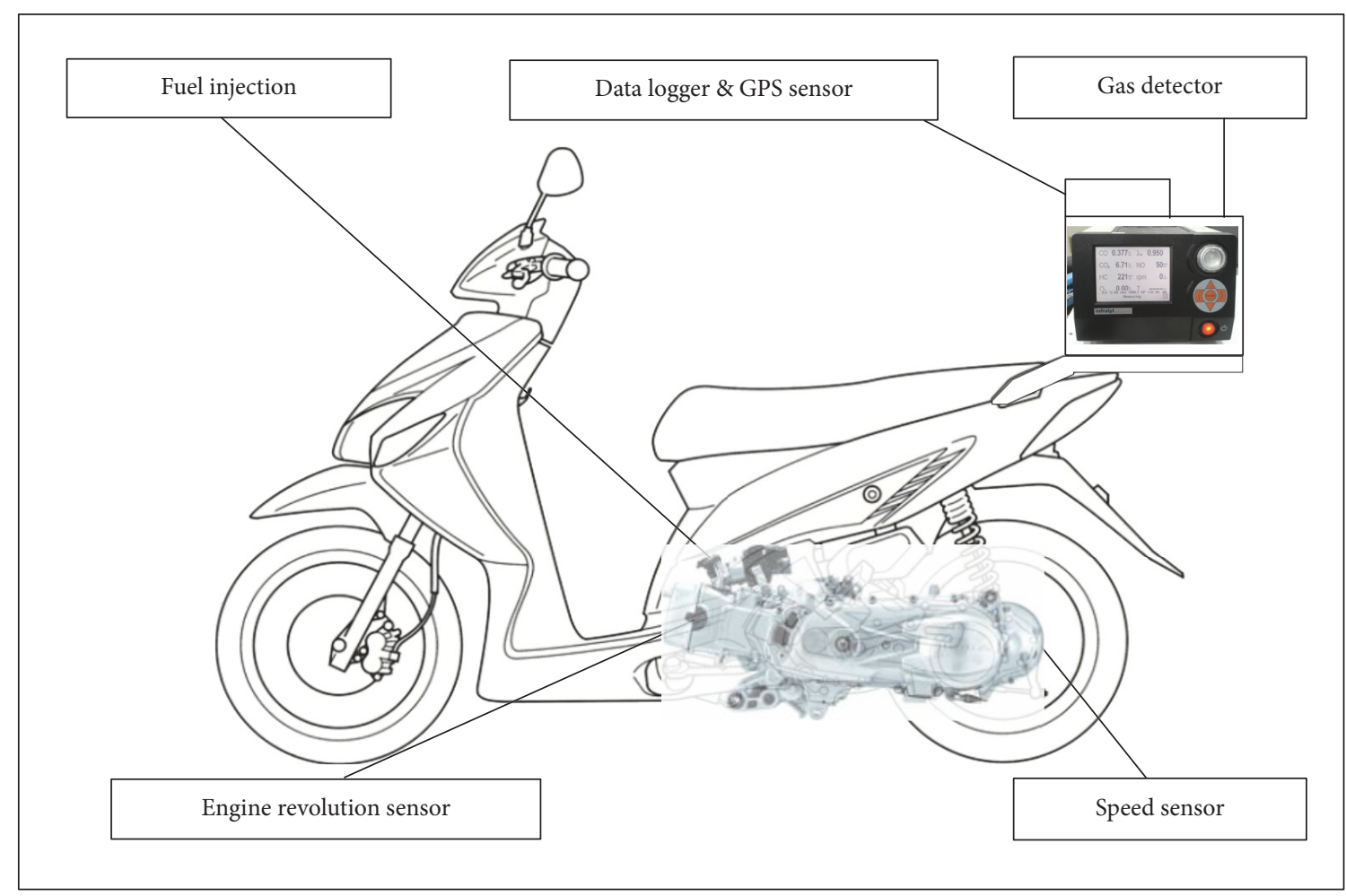

FIGURE 1: Component units of developed onboard measurement system.

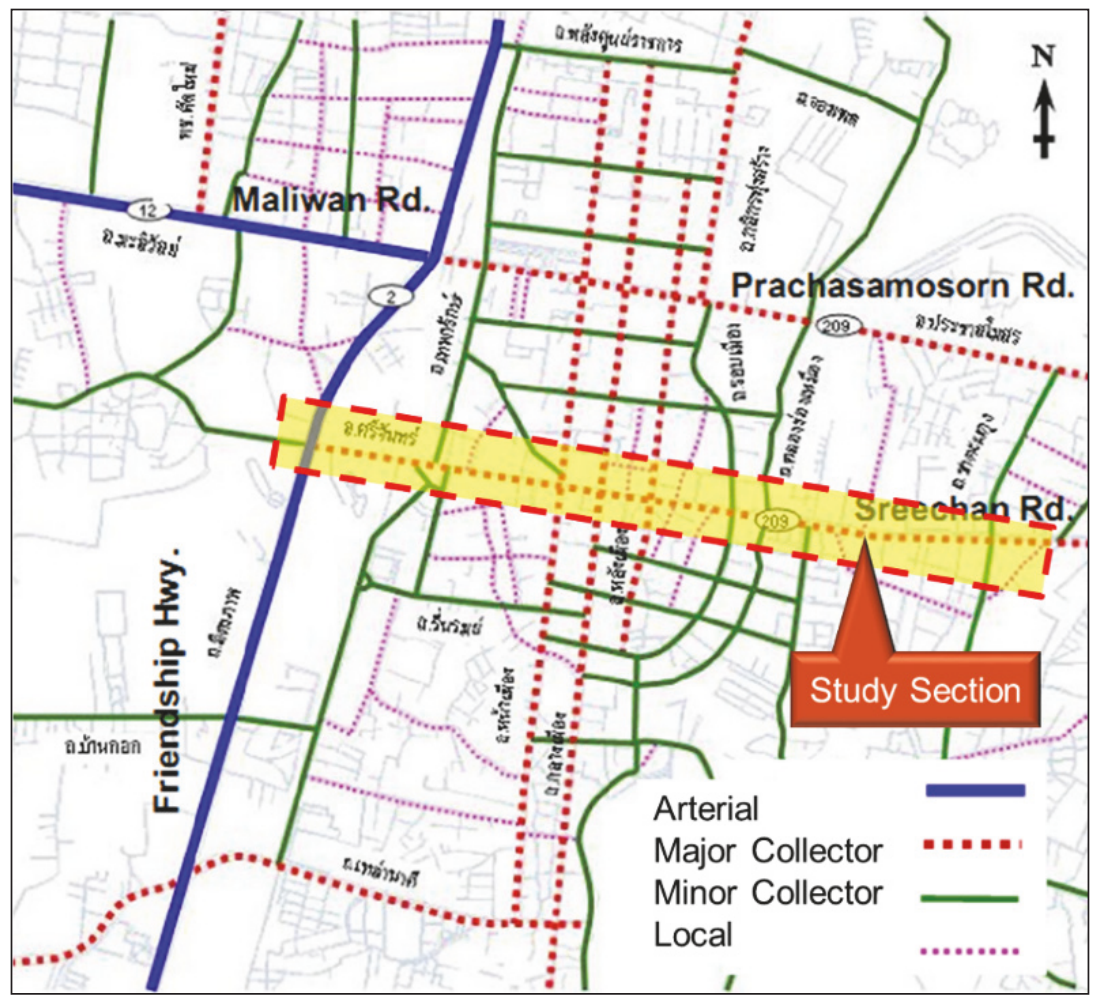

Figure 2: Sri Chan Rd. in Khon Kaen City road network. 
TABLE 1: Results of descriptive statistics analysis on on-road driving data.

\begin{tabular}{|c|c|c|c|}
\hline Number & Driving parameters & Mean & $\mathrm{SD}$ \\
\hline 1 & $T$ : driving time (s) & 1,279 & 176 \\
\hline 2 & $D$ : driving distance $(\mathrm{km})$ & 7.14 & 0.07 \\
\hline 3 & $\begin{array}{l}W: \text { total weight }(\mathrm{kg}) \\
(\text { Motorcycle weight }=98.8 \mathrm{~kg}, \text { fuel weight }=2.6 \mathrm{~kg} \text {, and mean weight of drivers }=60.4 \mathrm{~kg})\end{array}$ & 161.7 & 6.5 \\
\hline 4 & $V:$ average running speed $(\mathrm{km} / \mathrm{h})$ & 25.4 & 2.4 \\
\hline 5 & ACC: average acceleration $\left(\mathrm{m} / \mathrm{s}^{2}\right)$ & 0.59 & 0.09 \\
\hline 6 & DEC: average deceleration $\left(\mathrm{m} / \mathrm{s}^{2}\right)$ & -0.62 & 0.09 \\
\hline 7 & Pi: time spent at idle (\%) & 19.8 & 6.1 \\
\hline 8 & Pa: time spent in acceleration (\%) & 32.2 & 3.6 \\
\hline 9 & Pd: time spent in deceleration (\%) & 29.5 & 3.3 \\
\hline 10 & $M$ : average momentum $(\mathrm{kg} \cdot \mathrm{m} / \mathrm{s})$ & 1,140 & 121 \\
\hline 11 & FC: fuel consumption (ml/kg.km) & 0.1580 & 0.0171 \\
\hline 12 & $\mathrm{CO}_{2}: \mathrm{CO}_{2}$ emission $(\mathrm{g} / \mathrm{kg} \cdot \mathrm{km})$ & 0.2352 & 0.0403 \\
\hline 13 & CO: CO emission (g/kg.km) & 0.0070 & 0.0012 \\
\hline
\end{tabular}

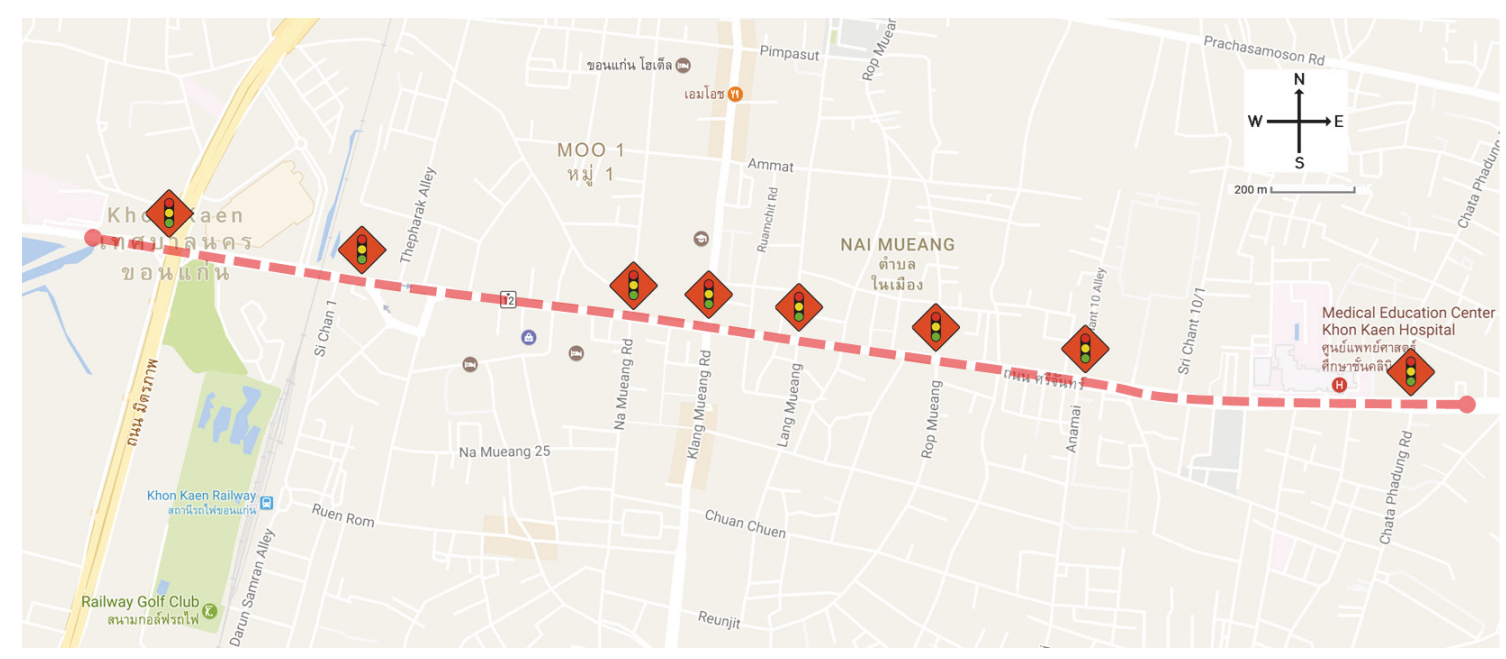

FIGURE 3: Selected study section located with 8 closing signalized intersections.

(\%). The weight of the driver might have an effect on fuel consumption and the emissions of the motorcycle, fuel consumption $(\mathrm{ml} / \mathrm{kg}-\mathrm{km})$, and $\mathrm{CO}_{2}$ and $\mathrm{CO}$ emissions $(\mathrm{g} / \mathrm{kg}-$ $\mathrm{km}$ ) were therefore calculated per travel distance and total weight (the sum of the weights of the motorcycle, fuel, and driver). Average momentum of a moving motorcycle (kg$\mathrm{m} / \mathrm{s}$ ) was also calculated by multiplying total weight with running speed. The results of descriptive statistics analysis on-road driving data are presented in Table 1.

It found that average driving distance $(D)$ of all drivers was $7.14 \mathrm{~km}$. Average driving time $(T)$ was $1,279 \mathrm{sec}$. Average total weight $(W)$, a summation of motorcycle weight, full fuel weight, and driver weight, was $161.7 \mathrm{~kg}$. Average running speed $(V)$ was $25.4 \mathrm{~km} / \mathrm{h}$. Average acceleration (ACC) was $0.59 \mathrm{~m} / \mathrm{s}^{2}$. Average deceleration (DEC) was $-0.62 \mathrm{~m} / \mathrm{s}^{2}$. Average of time spent at idle (Pi) was $19.8 \%$. Average of time spent in acceleration $(\mathrm{Pa})$ was $32.2 \%$. Average time spent in deceleration (Pd) was $29.5 \%$. Average momentum (M) was $1,139.9 \mathrm{~kg} \cdot \mathrm{m} / \mathrm{s}$. Average fuel consumption (FC) was $0.1580 \mathrm{ml} / \mathrm{kg} \cdot \mathrm{km}$. Average $\mathrm{CO}_{2}$ emission $\left(\mathrm{CO}_{2}\right)$ was $0.2352 \mathrm{~g} / \mathrm{kg} \cdot \mathrm{km}$ and average $\mathrm{CO}$ emission (CO) was $0.0070 \mathrm{~g} / \mathrm{kg} \cdot \mathrm{km}$. These driving parameters, $V$, ACC, DEC, Pi, $\mathrm{Pa}$, and $\mathrm{Pd}$, were consistent with those driving parameters found in the previous study of motorcycle driving cycle development in the same city [16].

3.2. Results of Driver Category by Fuel Consumption. The results of cluster analysis, categorized drivers by fuel consumption into three groups of low, medium, and high fuel consumption, are presented in Table 2. The results revealed that the group of drivers who consumed low fuel consumption emitted the lowest emissions of $\mathrm{CO}_{2}$ and $\mathrm{CO}$, yet their speed, acceleration, deceleration, and momentum were higher than the other groups. Obviously, their proportion of idle time was the lowest.

3.3. Results of Driver Category by On-Road Driver Behavior. The results of cluster analysis categorized by on-road driver 
TABLE 2: Results of driver category by fuel consumption.

\begin{tabular}{|c|c|c|c|c|c|c|c|c|c|c|c|}
\hline Group & Driver number & FC & $\mathrm{CO}_{2}$ & $\mathrm{CO}$ & V & ACC & DEC & $\mathrm{Pi}$ & $\mathrm{Pa}$ & $\mathrm{Pd}$ & $M$ \\
\hline Low FC & $3,7,9,11,15,16$ & 0.1348 & 0.1888 & 0.0064 & 27.83 & 0.63 & -0.67 & 12.8 & 35.9 & 32.9 & 1,295 \\
\hline Middle FC & $5,6,13,14,18,19,22,23,24,30$ & 0.1507 & 0.2269 & 0.0070 & 25.99 & 0.61 & -0.64 & 19.1 & 32.5 & 30.2 & 1,165 \\
\hline High FC & $1,2,4,8,10,12,17,20,21,25,26,28,29$ & 0.1745 & 0.2653 & 0.0077 & 23.71 & 0.58 & -0.61 & 23.4 & 30.5 & 27.8 & 1,045 \\
\hline
\end{tabular}

FC: fuel consumption $(\mathrm{ml} / \mathrm{kg} \cdot \mathrm{km}), \mathrm{CO}_{2}: \mathrm{CO}_{2}$ emission $(\mathrm{g} / \mathrm{kg} \cdot \mathrm{km}), \mathrm{CO}: \mathrm{CO}$ emission $(\mathrm{g} / \mathrm{kg} \cdot \mathrm{km}), V:$ average running speed, excluding idle periods $(\mathrm{km} / \mathrm{h})$, ACC: average acceleration or rate of change of speed above $0.27\left(\mathrm{~m} / \mathrm{s}^{2}\right)$, DEC: average deceleration or rate of change of speed below $-0.27\left(\mathrm{~m} / \mathrm{s}^{2}\right)$, Pi: time spent at idle or portion of time at zero speed (\%), Pa: time spent in acceleration or portion of time accelerating for $\geq 0.27 \mathrm{~m} / \mathrm{s}^{2}$ (\%), Pd: time spent in deceleration or portion of time decelerating for $\leq-0.27 \mathrm{~m} / \mathrm{s}^{2}(\%)$, and $M$ : average momentum $(\mathrm{kg} \cdot \mathrm{m} / \mathrm{s})$.

TABLE 3: Results of driver category by driving style.

\begin{tabular}{|c|c|c|c|c|c|c|c|c|c|c|c|}
\hline Group & Driver number & $\mathrm{FC}$ & $\mathrm{CO}_{2}$ & $\mathrm{CO}$ & V & ACC & $\mathrm{DEC}$ & $\mathrm{Pi}$ & $\mathrm{Pa}$ & $\mathrm{Pd}$ & $M$ \\
\hline Aggressive & $3,8,7,9,13,23$ & 0.1441 & 0.2013 & 0.0070 & 28.1 & 0.72 & -0.77 & 16.9 & 35.7 & 31.9 & 1,265 \\
\hline Nonaggressive & $\begin{array}{c}1,2,4,5,6,10,11 \\
12,14,15,16,17 \\
18,19,20,21,22 \\
24,25,26,28 \\
29,30\end{array}$ & 0.1611 & 0.2427 & 0.0071 & 24.7 & 0.56 & -0.59 & 20.2 & 31.3 & 29.0 & 1,108 \\
\hline
\end{tabular}

FC: fuel consumption $(\mathrm{ml} / \mathrm{kg} \cdot \mathrm{km}), \mathrm{CO}_{2}: \mathrm{CO}_{2}$ emission $(\mathrm{g} / \mathrm{kg} \cdot \mathrm{km}), \mathrm{CO}: \mathrm{CO}$ emission $(\mathrm{g} / \mathrm{kg} \cdot \mathrm{km}), \mathrm{V}:$ average running speed, excluding idle periods $(\mathrm{km} / \mathrm{h})$, ACC: average acceleration or rate of change of speed above $0.27\left(\mathrm{~m} / \mathrm{s}^{2}\right)$, DEC: average deceleration or rate of change of speed below $-0.27\left(\mathrm{~m} / \mathrm{s}^{2}\right)$, Pi: time spent at idle or portion of time at zero speed (\%), Pa: time spent in acceleration or portion of time accelerating for $\geq 0.27 \mathrm{~m} / \mathrm{s}^{2}$ (\%), Pd: time spent in deceleration or portion of time decelerating for $\leq-0.27 \mathrm{~m} / \mathrm{s}^{2}(\%)$, and $M$ : average momentum $(\mathrm{kg} \cdot \mathrm{m} / \mathrm{s})$.

behavior into two groups of aggressive and nonaggressive are presented in Table 3. The results revealed that the group of nonaggressive drivers, ecodriving drivers, consumed fuel and emitted emissions of $\mathrm{CO}_{2}$ and $\mathrm{CO}$ higher than the group of aggressive drivers. Noticeably, the proportion of idle time of the group of nonaggressive drivers was higher than the group of aggressive drivers. This implies that proportion of idle time was the driving parameter which significantly influenced fuel consumption, $\mathrm{CO}_{2}$ and $\mathrm{CO}$ emissions, rather than ecodriving behavior when motorcycles were driven on a congested and dense signalized road. They would penetrate into the stop line by overtaking a queue of vehicles under congestion, yet they would make frequent stops at signalized intersections to wait for green lights. A higher proportion of idle time or more frequent and longer time stopping for green lights caused higher fuel consumption and emissions of $\mathrm{CO}_{2}$ and $\mathrm{CO}$.

\section{Conclusion and Recommendations}

This study concluded that the traffic control system mainly influenced fuel consumption and emissions of $\mathrm{CO}$ and $\mathrm{CO}_{2}$ from motorcycles, rather than driving behavior while driving on an urban road presenting congested traffic and dense signalized intersections. A proportion of idle time significantly influenced fuel consumption and emissions while driving on a densely signalized and congested urban road. The study also presented the limitation of ecodriving behavior of motorcycle on network level which presents congested traffic and dense signalized intersections. Notably, high technology traffic control and management, such as an advanced area and coordinated signal control system with advanced information regarding signal phases and timing to vehicles travelling on a signalized corridor, would reduce the stop and delay of traffic at signalized intersections. The availability of an engine-stop installed on motorcycles would reduce fuel consumption and emissions when stopping at a signalized intersection.

For future studies, a similar collection of on-road driving data should be implemented on road networks without signalized control systems and lower traffic volume, in order to study driver behavior influencing the fuel consumption and emissions of a motorcycle. The results may be applied to develop an ecodriving cycle system for motorcycles. In addition to that, the study on providing advanced information regarding signal phases and timing to vehicles travelling on a signalized corridor, extending from cars $[25,26]$ to motorcycles, ought to be evaluated for its concept, whereby the motorcyclist would adjust his velocity for the minimizing of stopping time at a signalized intersection.

\section{Conflicts of Interest}

The authors declare that they have no conflicts of interest.

\section{Acknowledgments}

The authors would like to express their appreciation to the Asian Transportation Research Society (ATRANS) and the Farm Engineering and Automatic Control Technology Research Group (FEAT) of Khon Kaen University for financial support on this research work.

\section{References}

[1] V. T. Q. Truc and N. T. Kim Oanh, "Roadside BTEX and other gaseous air pollutants in relation to emission sources," Atmospheric Environment, vol. 41, no. 36, pp. 7685-7697, 2007.

[2] Department of Land Transport (DLT), "Accumulated Number of Vehicle by Fuel Type as of 31st December 2015," 2015, https://www.dlt.go.th/. 
[3] ADB (Asian Development Bank), Reduction Vehicle Emission Program: Integrated Action Plan to Reduce Vehicle Emission in Vietnam, RETA 5937, Reducing Vehicle Emissions in Asia, 2002.

[4] H. Wang, C. Chen, C. Huang, and L. Fu, "On-road vehicle emission inventory and its uncertainty analysis for Shanghai, China," Science of the Total Environment, vol. 398, no. 1-3, pp. 60-67, 2008.

[5] S. K. Sahu, G. Beig, and N. Parkhi, "Critical emissions from the largest on-road transport network in South Asia," Aerosol and Air Quality Research, vol. 14, no. 1, pp. 135-144, 2014.

[6] A. Fukuda, T. Satiennam, H. Ito, D. Imura, and S. Kedsadayurat, "Study on estimation of VKT and fuel consumption in Khon Kaen City, Thailand," Journal of the Eastern Asia Society for Transportation Studies, vol. 10, pp. 113-130, 2013.

[7] World Conference on Transport Research Society (WCTRS), "Putting Transport into Climate Policy AgendaRecommendations from WCTRS to COP18," Report, 2012.

[8] T. Satiennam, S. Jaensirisak, N. Natevongin, and W. Kowtanapanich, "Public transport planning for a motorcycle dominated community," Journal of the Eastern Asia Society for Transportation Studies, vol. 9, pp. 970-985, 2011.

[9] T. Satiennam, W. Satiennam, P. Tankasem, P. Jantosut, J. Thengnamlee, and W. Khunpumphat, "A study of potential electric motorcycle use to support a low carbon society: case of a developing Asian city," Advanced Materials Research, vol. 931932, pp. 541-545, 2014.

[10] B. Beusen, S. Broekx, T. Denys et al., "Using on-board logging devices to study the longer-term impact of an eco-driving course," Transportation Research Part D: Transport and Environment, vol. 14, no. 7, pp. 514-520, 2009.

[11] J. N. Barkenbus, "Eco-driving: an overlooked climate change initiative," Energy Policy, vol. 38, no. 2, pp. 762-769, 2010.

[12] M. Sivak and B. Schoettle, "Eco-driving: strategic, tactical, and operational decisions of the driver that influence vehicle fuel economy," Transport Policy, vol. 22, pp. 96-99, 2012.

[13] K. Boriboonsomsin, A. Vu, and M. Barth, "Eco-Driving: pilot evaluation of driving behavior changes among U.S. drivers," Tech. Rep. UCTC-FR-2010-2020, 2010.

[14] M. S. Alam and A. McNabola, "A critical review and assessment of Eco-Driving policy \& technology: Benefits \& limitations," Transport Policy, vol. 35, pp. 42-49, 2014.

[15] A. Seedam, T. Satiennam, T. Radpukdee, and W. Satiennam, "Development of onboard motorcycle system to measure on road driving pattern," Advanced Materials Research, vol. 931932, pp. 1303-1307, 2014.

[16] A. Seedam, T. Satiennam, T. Radpukdee, and W. Satiennam, "Development of an onboard system to measure the on-road driving pattern for developing motorcycle driving cycle in Khon Kaen city, Thailand," IATSS Research, vol. 39, no. 1, pp. 79-85, 2015.

[17] D. Schmidt, T. Su, K. Goney, P. Farrell, and M. Corradini, "Detection of cavitation in fuel injector nozzles," in Proceedings of the 8th ISTP Conference, San Francisco, Calif, USA, 1995.

[18] J. Desantes, R. Payri, F. Salvador, and J. Gimeno, "Measurements of spray momentum for the study of cavitation in diesel injection nozzles," SAE Technical Paper 2003-01-0703, 2003.

[19] F. Payri, V. Bermúdez, R. Payri, and F. J. Salvador, “The influence of cavitation on the internal flow and the spray characteristics in diesel injection nozzles," Fuel, vol. 83, no. 4-5, pp. 419-431, 2004.
[20] SIRDC, "A master plan of Khon Kaen transit system," Final Report, Khon Kaen Municipality and Sustainable Infrastructure Research and Development Center (SIRDC), Khon Kaen University, Khon Kaen, Thailand, 2008.

[21] K. S. Chen, W. C. Wang, H. M. Chen et al., "Motorcycle emissions and fuel consumption in urban and rural driving conditions," Science of the Total Environment, vol. 312, no. 1-3, pp. 113122, 2003.

[22] J.-H. Tsai, H.-L. Chiang, Y.-C. Hsu, B.-J. Peng, and R.-F. Hung, "Development of a local real world driving cycle for motorcycles for emission factor measurements," Atmospheric Environment, vol. 39, no. 35, pp. 6631-6641, 2005.

[23] H. Y. Tong, H. D. Tung, W. T. Hung, and H. V. Nguyen, "Development of driving cycles for motorcycles and light-duty vehicles in Vietnam," Atmospheric Environment, vol. 45, no. 29, pp. 5191-5199, 2011.

[24] T. Nutramon and C. Supachart, "Influence of driving cycles on exhaust emissions and fuel consumption of gasoline passenger car in Bangkok," Journal of Environmental Sciences, vol. 21, no. 5, pp. 604-611, 2009.

[25] M. Barth, S. Mandava, K. Boriboonsomsin, and H. Xia, "Dynamic ECO-driving for arterial corridors," in Proceedings of the IEEE Forum on Integrated and Sustainable Transportation Systems (FISTS '11), pp. 182-188, Vienna, Austria, June-July 2011.

[26] H. Xia, K. Boriboonsomsin, and M. Barth, "Indirect networkwide energy/emissions benefits from dynamic eco-driving on signalized corridors," in Proceedings of the 14th IEEE International Intelligent Transportation Systems Conference (ITSC '11), pp. 329-334, IEEE, Washington, DC, USA, October 2011. 


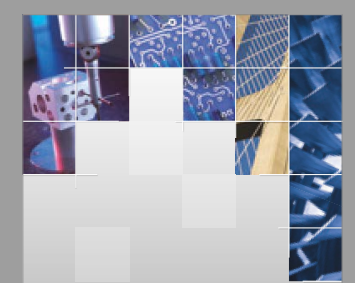

\section{Enfincering}




The Scientific World Journal

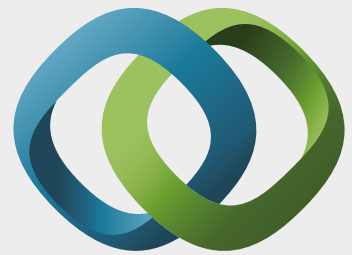

\section{Hindawi}

Submit your manuscripts at

https://www.hindawi.com
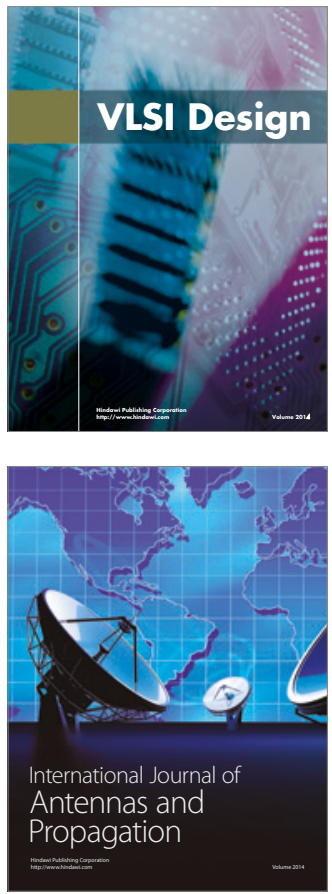

\section{Rotating}

Machinery

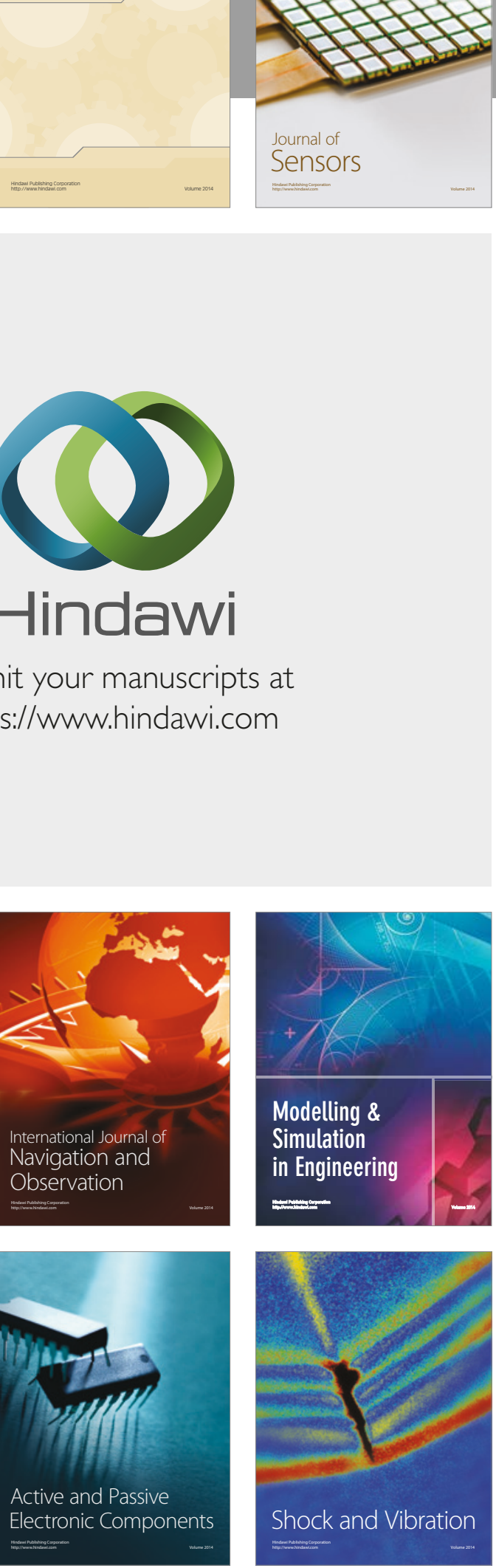
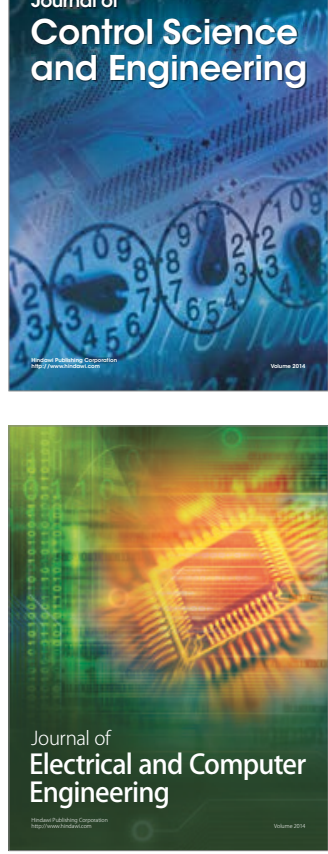

Distributed

Journal of

Control Science

and Engineering
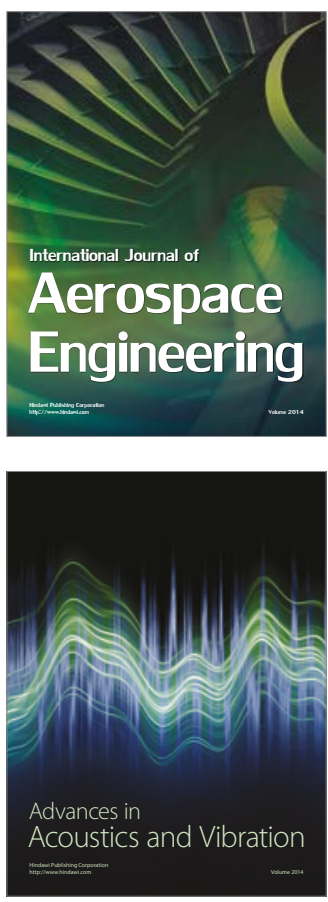

Sensor Networks 